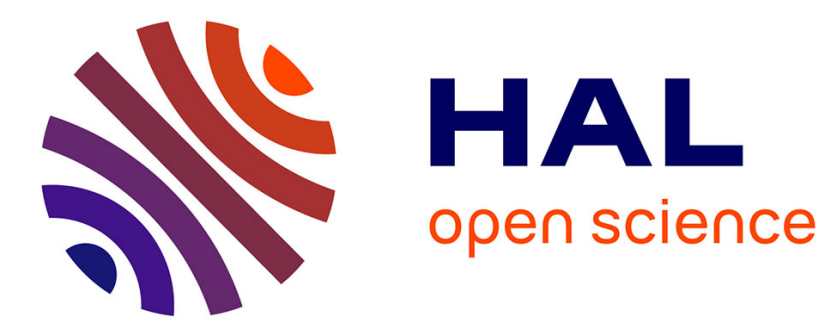

\title{
Joint Audit, Game Theory, and Impairment-Testing Disclosures
}

Luc Paugam, Jean-François Casta

\section{To cite this version:}

Luc Paugam, Jean-François Casta. Joint Audit, Game Theory, and Impairment-Testing Disclosures. 1er Workshop "Audit" - EM Lyon / IAE Poitiers / Université Paris-Dauphine, Mar 2012, Ecully, France. halshs-00671613v2

\section{HAL Id: halshs-00671613 https://shs.hal.science/halshs-00671613v2}

Submitted on 19 Mar 2012

HAL is a multi-disciplinary open access archive for the deposit and dissemination of scientific research documents, whether they are published or not. The documents may come from teaching and research institutions in France or abroad, or from public or private research centers.
L'archive ouverte pluridisciplinaire HAL, est destinée au dépôt et à la diffusion de documents scientifiques de niveau recherche, publiés ou non, émanant des établissements d'enseignement et de recherche français ou étrangers, des laboratoires publics ou privés. 


\title{
Joint Audit, Game Theory, and Impairment-Testing Disclosures
}

\author{
Luc Paugam \\ University Paris-Dauphine, luc.paugam@dauphine.fr \\ Jean-François Casta \\ University Paris-Dauphine, jean-francois.casta@dauphine.fr
}

This version: March 15, 2012

Acknowledgements. The authors are member of Dauphine Recherche en Management (DRM), CNRS Unit, UMR 7088. We gratefully acknowledge comments by Pierre Astolfi and the financial support of the FBF Chair in Corporate Finance. 


\title{
Joint Audit, Game Theory, and Impairment-Testing Disclosures
}

\begin{abstract}
:
We examine the consequences on impairment testing disclosures of auditor-pair choice made by French listed companies where two (joint) auditors are required by law. Managers are likely to manipulate impairment-testing disclosures since it relies on unverifiable fair value estimates (e.g., goodwill). From a simple game theory model, we demonstrate that a Big-4 auditor paired with a non-Big 4 auditor increase auditors' incentives to force firms to disclose more because Big 4 auditor fully bears reputation costs. Using a disclosure score for firms composing the French SBF 120 index from 2006 to 2009, we provide evidence that combination of Big 4 / non-Big 4 auditors generate higher impairment-related disclosures levels whereas the other combinations, i.e. two Big 4 or two non-Big 4 , tend to decrease the level of impairment-related disclosures. These empirical results are consistent with our model predictions and robust to various controls variables (e.g., size, risk, year and firm fixed effects).
\end{abstract}

\section{Keywords:}

Joint Audit - Impairment Test - Game Theory - Prisoner's Dilemma - Disclosures - IAS 36 


\section{Introduction}

In France, publicly listed companies preparing consolidated financial statements are required to be audited by two unrelated auditors. This requirement introduces complexity in the typical context of the choice between Big 4 and non-Big 4 auditors prevailing in most developed countries. We aim at assessing the consequences of the different possible combinations on financial disclosures that are likely to be manipulated by managers, i.e. impairment-testing disclosures. Ramanna (2008), Ramanna and Watts (2009) and Li and Sloan (2011) demonstrate that goodwill impairments tend to be manipulated by managers because the procedure relies on unverifiable fair value estimates. Associated impairment-testing disclosures are also likely to be manipulated in order to support the tests' results. Auditors play a central role in maintaining the objectivity and fairness of impairment tests and can take corrective actions to increase impairment-testing disclosures.

Francis et al. $(2009,37)$ find that in France, "firms with one or two Big 4 auditors are less likely to have income-increasing abnormal accruals than other firms. [...] firms audited by two Big 4 auditors are even less likely to have income-increasing accruals." Our research question is to determine if an association exists between auditor-pair choice and financial reporting quality using impairment-testing management. We suggest testing the association between auditor-pair choice and impairment-testing disclosures because such disclosures are usually manipulated and are notoriously related to public firms' biggest individual asset for which fair value estimates is required, i.e. goodwill.

We show that from a game theory perspective, two Big 4 auditors sharing equally the reputation costs associated with low impairment-related disclosures, could lead to the prisoner's dilemma-solution, according to which doing nothing is the dominant strategy. On the opposite, as Big 4 auditors paired with non-Big 4 auditors bear a large part, if not all, of the reputation costs associated with impairment-testing management, the dominant strategy for the auditor would be to take corrective actions increasing the level of financial disclosures. We demonstrate that the "do nothing" strategy is more likely to be dominant for a Big 4 paired with another Big 4 auditor, leading to a socially suboptimal equilibrium where the level of disclosures is low. On the other hand, Big 4 auditors paired with non-Big 4 auditors are more likely to lead to higher levels of disclosures. We test these theoretical predictions.

Our sample consists of all non-financial French firms composing the SBF 120 index (120 biggest French market cap) from 2006 to 2009. Using a detailed hand-collected index 
composed of 55 items focusing on impairment-testing disclosures from firms' annual reports, we demonstrate that Big 4 auditors paired with non-Big 4 auditors generate higher levels of disclosures than other combinations, i.e. two Big 4 or two non-Big 4 , which are significantly associated with lower levels of impairment related disclosures. Our results are consistent with the prediction of our game theory model, i.e. as Big 4 auditors bear a large part of reputation costs when they are paired with non-Big 4 auditors, they are more likely to force firms to disclose more.

We contribute to the literature at two levels. First, we deepen the understanding of the consequences of the French joint audit requirement on financial statements' quality. Hence, strategic interactions between joint auditors matter in terms of financial statements' quality. To the best of our knowledge, this paper is the first to use game theory to study joint audit. Second, we challenge the idea that two Big 4 auditors necessarily improve financial statements' quality. Considering strategic interactions between joint auditors, we provide evidence that the relation between joint auditors and financial statement's quality may be more complex than two Big 4 are better than one Big 4 which is better than none.

The remainder of this paper is organized as follows. We review related literature in section 2 . Our simple game theory model and our hypotheses are exposed in section 3. We present our data, empirical analysis and findings in section 4 . We conclude in section 5.

\section{Overview of Related Literature}

Francis et al. (2009) analyze the consequences of France's joint audit requirement on earnings quality on a sample of 261 observations and find that Big 4 auditor-pairs are associated with lower levels of income-increasing abnormal accruals. Big 4 auditors paired with non-Big 4 auditors are also associated with lower levels of income increasing abnormal accruals but to a lesser extent. Francis et al. (2009) conclude that a pecking order exists with regards to earnings quality and auditor-pair choices. We suggest examining this pecking order from a different perspective by looking at other measures of financial reporting quality, i.e. financial disclosures, and considering interaction between auditors.

Impairments of assets are typically perceived as a negative asset pricing signal by market participants (Fields et al. 2001), which provides a primary incentive for firms to avoid booking or delaying impairment of assets. Multiple other incentives exist for managers to 
avoid or delay impairment recognition including debt and compensation contracts (Watts and Zimmerman 1986) or management reputation (Francis et al. 1996). Consequently Ramanna and Watts (2009) or Li and Sloan (2011) find that impairment of assets are subject to a high degree of manipulation by managers which benefit from a context of subjectivity permissible by the publication of recent standards, i.e. IAS 36 (IASB 2004) internationally and FAS 142 (FASB 2001) in the US. External auditors play an important role in maintaining the objectivity and fairness of impairment tests, particularly with regards to the accuracy and completeness of impairment-testing disclosures.

As the French Security Law $^{1}$ requires that each joint auditor verifies the work undertaken by the other independent auditor leading to the joint audit report, the joint audit statement may be viewed as the outcome of a non-cooperative game between the two auditors.

Game theory has already been used to describe relations between a firm and its (single) auditor. Strategic relations are analyzed in a cooperative game set (e.g., Demski and Swieringa (1974), Hatherly et al. (1996)). Demski and Swieringa (1974) advance that "the fee structure is (cooperatively) agreed upon" between the auditor and the auditee and that they both share the potential legal costs associated with unacceptable accounting methods. Hatherly et al. (1996) and Antle and Nalebuff (1991) also consider that auditor and auditee jointly agree on a strategy and the auditing process. On the other hand, other papers suppose non-cooperative interactions between auditor and auditee (e.g., Fellingham and Newman (1985), Matsumura and Tucker (1992), (Cook et al. 1997)). In this setting the auditor can take actions to control the auditee and the conditions for the socially desirable outcome to occur are studied. To our knowledge, game theory has never been used to model strategic interactions between joint auditors.

In the next section we describe our simple game model and our hypotheses.

\footnotetext{
${ }^{1}$ French Financial Security Law (2003). «Loi No 2003-706 du 1 août 2003 de sécurité financière, version consolidée au $1^{\text {er }}$ avril $2006 »$, available at http://www.legifrance.gouv.fr. Francis et al. $(2009,38)$ provide details on the specificity of the audit market in France.
} 


\section{Simple Joint Audit Game and Development of Hypotheses}

As firms may be reluctant to voluntary disclose, the socially desirable outcome of audit is to force firms to produce sufficient levels of disclosures. The competitive nature of the audit industry can be structured as a non-cooperative game between auditors. When investigating the level of information produced by firms, auditors decide whether or not taking corrective actions, hence conditioning the level of firms' disclosures.

\subsection{Two Player Game with Homogeneous Auditor Pair}

We hypothesize that joint auditors have the choice between two strategies: taking "corrective actions" to increase the level of disclosure or taking "no action." We further hypothesize that:

- Taking corrective actions to increase the level of disclosure generates costs $\mathrm{C}_{C A}$ for auditors. These costs are shared equally between the two auditors $\left(1 / 2 * \mathrm{C}_{C A}\right)$ when they both decide to take corrective actions (the cost of "no action" are set to zero). Auditors bear the full amount of costs $\mathrm{C}_{C A}$ when they decide to take corrective actions alone.

- If no auditor takes corrective action the level of voluntary disclosure will be "low," but one auditor choosing to take "corrective actions" is sufficient to generate the socially optimal "high" level of disclosure (solutions marked with a star in Table 1).

\section{[Insert Table 1 About Here]}

- Finally, if auditors are associated with a low-disclosing firm, they bear reputation costs $\mathrm{C}_{R E P}$. Those costs are shared equally $\left(1 / 2 * \mathrm{C}_{R E P}\right)$ between the joint-auditors.

With a homogenous auditor pair the players, strategies and payoff can be represented in a reduced strategic form as in Table 2.

[Insert Table 2 About Here]

The Nash equilibrium solution for this two person game will depend on the relative value of the "corrective actions" strategy's costs as compared to the reputation costs generated by the "no-action" strategy.

\section{Lemma 1:}

If $1 / 2 * \mathrm{C}_{R E P}<\mathrm{C}_{C A}$ then the Nash equilibrium solution is given when both firm do not take corrective actions similar to the prisoners' dilemma solution. 
Proof: Auditor \#1 "no action" strategy dominates when auditor \#2 chooses to take "corrective actions" since $-1 / 2 * \mathrm{C}_{C A}<0$ and also dominates when auditor \#2 chooses to make "no-action" since $1 / 2 * C_{R E P}<C_{C A}$ by hypothesis. The same argument holds true for the other player.

The meaning of this result is that if reputation costs are low enough, either because they are low in absolute terms or because they are shared by the two auditors, then the auditors will choose to take "no-action" and the level of disclosure will be socially too low. ${ }^{2}$ This is the typical case in the prisoners' dilemma game. Therefore we make the following hypothesis:

H1: Firms with a homogeneous auditor pair are more likely to produce a lower level of impairment-testing disclosures than other firms.

In the next paragraph, we introduce heterogeneity among auditors.

\subsection{Introducing Big 4 / Non-Big 4 Auditor Types}

We now introduce two types of players: Big 4 and non-Big 4 auditors. We assume the following differences between the two types of auditors:

- Because of economies of scale and human capital, the costs of taking corrective actions to achieve the same level of disclosures for non-Big 4 are greater than for Big 4 such that $C_{C A}^{N B 4}=k * C_{C A}$ (with $\left.\mathrm{k}>1\right){ }^{3}$ We hypothesize a linear relationship between the costs for non-Big 4 and Big 4 auditors. ${ }^{4}$ If both auditors decides to take corrective actions, the costs is reduced for Big 4 auditor to $1 / 2 * \mathrm{C}_{C A}$, and to $\mathrm{k} / 2 * \mathrm{C}_{C A}$ for non-Big 4 auditor.

- The reputation costs $\mathrm{C}_{R E P}$ generated when an auditor is associated with low disclosingfirm are higher for a Big 4 than for non-Big 4 because they have "more to lose" (DeAngelo 1981, 183). In our model, we hypothesize that all the reputation costs fall on the Big 4 auditor and none fall on the non-Big 4 auditor.

With a heterogeneous auditor pair the players, strategies and payoff can be represented in a reduced strategic form as in Table 3.

[Insert Table 3 About Here]

\footnotetext{
${ }^{2}$ One could also argue that two Big 4 auditors reduce the absolute level of reputation costs since they both signal the quality of financial statements.

${ }^{3}$ We believe that impairment-testing disclosures offer a great setting since they rely on fair value that require a high level of human capital that non-Big 4 auditors are less likely to own.

${ }^{4} \mathrm{~A}$ fixed cost $\mathrm{X}$ could also be added to $\mathrm{C}_{\mathrm{CA}}$ such that $C_{C A}^{N B 4}=C_{C A}+X$.
} 
As in the previous case, the Nash equilibrium solution for this two person game with two types of auditors will depend on the relative value of the "corrective actions" strategy's costs as compared to the reputation costs generated by low disclosure.

\section{Lemma 2:}

If $\mathrm{C}_{R E P}>\mathrm{C}_{C A}$ then the Nash equilibrium solution is given when Big-4 auditor takes "corrective actions" and non-Big 4 auditor chooses to free ride by taking "no-action."

\section{Proof:}

The non-Big 4 auditor strategy of taking "no action" strictly dominates the other strategy since $-\mathrm{k}^{*} \mathrm{C}_{C A}<-\mathrm{k} / 2 * \mathrm{C}_{C A}<0$. Given the non-Big 4 strategy, the Big 4 strategy of taking "correcting actions" dominates the "no-action" strategy if and only if $\mathrm{C}_{R E P}>\mathrm{C}_{\mathrm{CA}}$.

The understanding of this result is that as non-Big 4 auditors bear to a much lesser extent reputation costs (here none) and face higher costs to implement the corrective actions strategy, they have no incentive to take actions, i.e. the strategy "no action" strictly dominates the other strategy. As a result the non-Big 4 auditor acts as a free rider. Given the choice of the non-Big 4 auditor, the Big 4 auditor will choose to take corrective actions only if the reputation costs associated with low disclosure (that they fully bear) exceed the costs of taking corrective actions alone. As a result, we make the following assumption:

H2: Firms with a heterogeneous auditor pair are more likely to produce higher level of impairment-testing disclosures than other firms.

In the next section we provide empirical tests of $\mathrm{H} 1$ and $\mathrm{H} 2$.

\section{Empirical Application}

\subsection{Measuring the Level of Impairment-Testing Disclosures}

Standard IAS 36 "Impairment of assets" (IASB 2004) prescribes the procedures and disclosures required to perform impairment tests. Standard IAS 36 covers a large range of assets from tangible to intangible assets, including goodwill. Impairments are required to be reported in profit or loss if the net book value of an asset is higher than the recoverable value being the highest of fair value or value in use. If impossible to determine the recoverable amount for an individual asset, the standard prescribes to determine recoverable amount for 
groups of assets known as cash generating units. In order to include individual assets in a specific cash generating unit, the associated cash flows must be independent from cash flows stemming from other cash generating units. Goodwill is typically allocated to one or several cash generating units and tested indirectly within the cash generating unit. The fair value estimate of the cash generating unit is typically based either on a discounted cash flow approach or on a relative valuation method.

Impairments of assets are based on management estimates. Managers usually acknowledge that they use specific assumptions for impairment testing purposes. For example in AlcatelLucent's 2008 annual report (p. 245) the management states: "The recoverable values of our goodwill and intangible assets, as determined for the impairment tests performed by the Group, are based on key assumptions which could have a significant impact on the consolidated financial statements. These key assumptions include, among other things, the following elements: discount rate; and projected cash-flows [...]."

For French listed firms, disclosures with regards to these impairment testing procedures vary greatly from a firm to another. For instance the French pharmaceutical company Stallergenes in its 2006 annual report's "main accounting methods" section (p. 41), provides only minimal narrative information with regard to impairment tests such as "A writedown is recorded once a year or more frequently if events or changes in circumstances indicate the likelihood of impairment for that acquisition goodwill" and "If an impairment is identified, the recoverable of the CGU to which the acquisition goodwill belongs is assessed. An impairment is recognized as soon as the book value of the CGU to which the acquisition goodwill belongs exceeds the recoverable value." No further information concerning impairment tests is provided in the notes, although the firm owns a substantial amount of intangibles assets for which impairment tests are required to be performed at least once a year.

On the opposite, France Telecom's 2008 annual report contains a much greater amount of information regarding impairment-testing procedures. In its note 6 (p. 287-289), the company dedicates almost three pages to its impairment tests and provide a wide range of information. The management explains the level at which goodwill is tested, and provides in tables the key assumptions used in the estimation of recoverable amounts (e.g., growth rate to perpetuity, main cash generating units and groups of cash generating units, post and pre-tax discount rates used), as well as narrative explanations for specific countries. 
Considering this various disclosure levels and the incentives to manipulate impairment-testing disclosures, we examine every annual report produced by French non-financial 120 top-listed firms (SBF 120 index) from 2006 to 2009. We look for 55 items covering the main aspects of impairment-testing disclosures. Table 4 exhibits the main categories, sub-categories and number of items in each sub-category covered by our disclosure score.

[Insert Table 4 About Here]

By attributing one point by item that shows up in firm $i$ 's annual report for year $t$, the resulting score is computed as:

$$
\text { Score }_{i, t}=\frac{1}{55} \sum_{j=1}^{55} \text { Item }_{i, t} * 100
$$

We divide the sum of the items by the maximum number of points and multiply it by 100 in order to obtain the dependent variable Score ranging from 0 to 100.

As presented in Table 4, our disclosure score is quite comprehensive as it covers technical valuation aspects of impairment tests (e.g., discount rates, neutrality of the financing structure, terminal value issues) as well as qualitative aspects (e.g., presentation of the alternative fair value or value in use, use of independent experts).

In the next paragraph we explain our methodology to test the association between impairment-testing disclosures and auditor pair choice.

\subsection{Auditor-Pair Choice and Association with Impairment-Testing Disclosures}

To determine if the joint audit pair has an impact on the level of disclosures, we estimate model (2) using firm and year fixed effects, where Auditor_Pair is the main variable of interest:

$$
\begin{gathered}
\text { Score }_{i, t}=c+\mu_{i}+b_{1} * \text { Auditor_Pair }_{i, t}+b_{2} * \operatorname{Imp}_{i, t}+b_{3} * \text { Risk }_{i, t}+b_{4} * \text { Size }_{i, t}+ \\
b_{5} * \text { Float }_{i, t}+\text { Year }_{t}+\varepsilon
\end{gathered}
$$

Where for firm $i$ and year $t$ :

- Score $_{i, t}$ is our self-constructed score for firms' impairment related disclosures;

- Auditor_Pair ${ }_{i, t}$ is one of the three following dummy variables: 
- Big4_Big $4_{i, t}$ equaling 1 if both firm's external auditors are among the four largest audit companies;

- Big4_Small $l_{i, t}$ equaling 1 if one of the two external auditors is among the four largest audit companies and the other is not;

- Small_Small $i_{, t}$ equaling 1 if both firm's external auditors are not among the four largest audit companies;

- $\operatorname{Imp}_{i, t}$ is a dummy variable equaling 1 when the firm has an impairment of intangible asset;

- Risk $_{i, t}$ is the firm's 5-year beta;

- Size $_{i, t}$ is the natural logarithm of the firm's market value of equity;

- Float $_{i, t}$ is the percentage of firm's publicly exchanged equity (free float).

We expect the following relationships between the dependent and independent variables:

- a negative relationship between Score $_{i, t}$ and Auditor_Pair $r_{i, t}$ when it is defined as Big4_Big4 ${ }_{i, t}$ or Small_Small ${ }_{i, t,}$, because homogenous auditor-pair could be associated to lower levels of impairment-testing disclosures consistent with the prisoners' dilemma solution (hypothesis $\mathrm{H} 1$ );

- a positive relationship when Auditor_Pair ${ }_{i, t}$ is defined as Big4_Small ${ }_{i, t}$ as a heterogeneous auditor-pair could lead to a higher level of impairment-testing disclosures (consistent with our model predicting H1);

- a positive relationship with $I m p_{i, t}$ as the occurrence of an impairment could trigger additional disclosures explaining the impact and potential reasons for this bad news;

- a positive relationship is expected with $\operatorname{Risk}_{i, t}$ as risky firms need to reduce the external perception of their riskiness by producing additional disclosures;

- a positive relationship with Size $_{i, t}$ is expected as firm's size allows to dedicate more resources to the production of financial disclosures;

- a positive relationship is expected with Float $_{i, t}$ as outside investors are the primary users of annual reports. This increase the likelihood of finding additional disclosures in the annual report when free float represent a large portion of the equity.

We present the sample in the next section. 


\subsection{Data and Sample}

We start our sample with the 120 firms composting the SBF 120 index over the period 2006 to 2009 . We remove the 10 financial firms composing the index due to the specificities of the industry's disclosures. Due to missing variables for some firms, our final sample is composed of 94 firms and 355 firm-year observations.

The dispersion and evolution of the disclosure score is exhibited in Figure 1.

\section{[Insert Figure 1 About Here]}

The dispersion of the firms' scores in the sample is relatively high and firms improve their impairment-testing disclosures over the period 2006-2009.

Table 5 presents some descriptive statistics of the sample.

\section{[Insert Table 5 About Here]}

From Table 5, Panel A, it appears that $41 \%$ of the firms are audited by a Big 4 auditor-pair over the period, $56 \%$ of firms are audited by a Big 4 paired with a non-Big 4 auditor and the remaining $3 \%$ are audited by a pair of non-Big 4 auditors. Changes of either one or two auditors during a year does not occur frequently, i.e. only $6 \%$ of the time.

The mean (median) impairment-testing disclosure score for the four-year period is 53 points (54 points) and range from a minimum of 13 points and a maximum of 89 points over the period. The dispersion of the score measured by standard deviation is almost 17 points. The mean (median) risk of firms in the sample as proxied by 5-year beta is $0.84(0.84)$, the mean (median) size is 7.33 (7.24). The mean (median) percentage of firms' shareholder's equity that is publicly traded (free float) is $65 \%(67 \%)$. Finally impairment of assets occurs on average $41 \%$ of the time during the period 2006 to 2009.

From Table 5, Panel B, we can see that Score is positively correlated with Big4_Big4 and negatively correlated with Big4_Small, going against our hypotheses H1 and H2. However, these correlations are not statistically different from zero (at 10\%) and can be difficult to take into account without controlling for other factors (e.g., size or risk). As bigger firms disclose more, and are usually audited by two Big 4 auditors, the correlation could simply indicate the effect of size.

We present the results of our multivariate analysis, which introduce several control variables, in the next paragraph. 


\subsection{Empirical Findings}

The association between auditor-pair choice and impairment-related disclosures is tested with model (2). Table 6 exhibits the results of the panel estimation with year and firm fixed effects.

[Insert Table 6 About Here]

From Table 6, the main results are that pairs of Big 4 auditors significantly decrease the level of impairment related disclosures with a magnitude of approximately 7 points, whereas Big 4 auditors paired with non-Big 4 auditors increases the level of disclosures provided of approximately 6 points. The results are significant at the 5\% level using standard two-tails ttests. Pairs of non-Big 4 auditors (Small_Small) are associated with lower level of disclosures (negative sign on the coefficient) but the relation is not significant. However this case represents only $3 \%$ of the sample's observations. These results are consistent with our game theory model predictions, i.e. Big 4 auditors pair sharing the reputation costs are less likely to engage in forcing firms to disclosure more than a Big 4 auditor paired with a non-Big 4 auditor.

From the control variables presented in Table 6, it appears that Risk and Float significantly increase the level of impairment-testing disclosures. The score is increasing through time as the coefficient on the year dummies rises for years 2008 and 2009 confirming what was observed on Figure 1. Size and Imp variables do not appear to be significantly related with impairment-testing disclosures which are mandatory even in the absence of an impairment of asset.

\section{Conclusion}

Recent literature (e.g., Li and Sloan (2011), Ramanna (2008) and(Ramanna and Watts 2009)) demonstrate that recent standard publications allowing the use of unverifiable fair value estimates, i.e. FAS 142 (FASB 2001) and IAS 36 (IASB 2004), led to manipulation and delaying of impairment of assets. Impairment-testing disclosures are also likely to be distorted in order to enable managers to manipulate the outcome of their tests. In that context external auditors play a key role in ensuring that impairment tests are objectively conducted. French requirement of a joint audit is a unique opportunity to study if the decision making process is improved by the presence of two auditors.

Francis et al. (2009)'s results support the idea that Big 4 auditor paired with other Big 4 auditors are associated with higher earnings quality than only one Big 4 auditor paired with a 
non-Big 4 auditor, or than two non-Big 4 auditors. We test this pecking order in the context of impairment-testing disclosures using a simple game theory model. We demonstrate that homogeneity among auditor-pairs can lead to the prisoners' dilemma solution and a socially sub-optimal disclosure level. This situation is less likely to occur with a Big 4 paired with a non-Big 4 auditor as the Big 4 auditor fully bears the reputation costs. On a sample of French top-listed firms, we found that heterogeneous auditor-pairs lead to significantly increasing impairment-testing disclosures whereas Big 4 auditor-pairs generate significantly lower levels of impairment-testing disclosures. These results are consistent with our theoretical predictions.

One could argue that these results may be specific to impairment-testing disclosures. The relationship between auditor-pair choice and financial reporting quality could be tested with other type of disclosures or other proxy for financial reporting quality. France's unique setting offers a great field to test for costs and benefits associated with the joint audit requirement. 


\section{References}

Antle, R., and B. Nalebuff. 1991. Conservatism and auditor-client negotiations. Journal of Accounting Research 29 (3): 31-54.

Cook, J., D. Hatherly, L. Nadeau, and L. C. Thomas. 1997. Does cooperation in auditing matter? A comparison of a non-cooperative and a cooperative game model of auditing. European Journal of Operational Research 103 (3): 470-482.

DeAngelo, L. E. 1981. Auditor size and audit quality. Journal of Accounting \& Economics 3 (3): 183-199.

Demski, J. S., and R. J. Swieringa. 1974. A cooperative formulation of the audit choice problem. Accounting Review 49 (3): 506-513.

FASB. 2001. Statement of financial accounting standards (sfas) no. 142: Goodwill and other intangible assets. Norwalk, CT: Financial Accounting Standards Board.

Fellingham, J. C., and D. P. Newman. 1985. Strategic considerations in auditing. Accounting Review 60 (4): 634.

Fields, T. D., T. Z. Lys, and L. Vincent. 2001. Empirical research on accounting choice. Journal of Accounting \& Economics 31 (1-3): 255-307.

Francis, J., J. D. Hanna, and L. Vincent. 1996. Causes and effects of discretionary asset writeoffs. Journal of Accounting Research 34 (3): 117-134.

Francis, J. R., C. Richard, and A. Vanstraelen. 2009. Assessing france's joint audit requirement: Are two heads better than one? Auditing 28 (2): 35-63.

Hatherly, D., L. Nadeau, and L. Thomas. 1996. Game theory and the auditor's penalty regime. Journal of Business Finance \& Accounting 23 (1): 29-45.

IASB. 2004. International accounting standard (ias) no. 36: Impairment of assets. London: IASC Foundation Publications Department.

Li, K. K., and R. G. Sloan. 2011. Has goodwill accounting gone bad? Canadian Academic Accounting Association Annual Meeting, Toronto.

Matsumura, E. M., and R. R. Tucker. 1992. Fraud detection: A theoretical foundation. Accounting Review 67 (4): 753-782.

Ramanna, K. 2008. The implications of unverifiable fair-value accounting: Evidence from the political economy of goodwill accounting. Journal of Accounting and Economics 45: 253-281.

Ramanna, K., and R. L. Watts. 2009. Evidence from goodwill non-impairments on the effects of using unverifiable estimates in financial reporting. Working Papers -- Harvard Business School Division of Research: 1-41.

Watts, R. L., and Zimmerman. 1986. Positive accounting theory. NJ: Edgewood Cliff. 
Figure 1 - Repartition of the Impairment-Testing Disclosure Score from 2006 to 2009

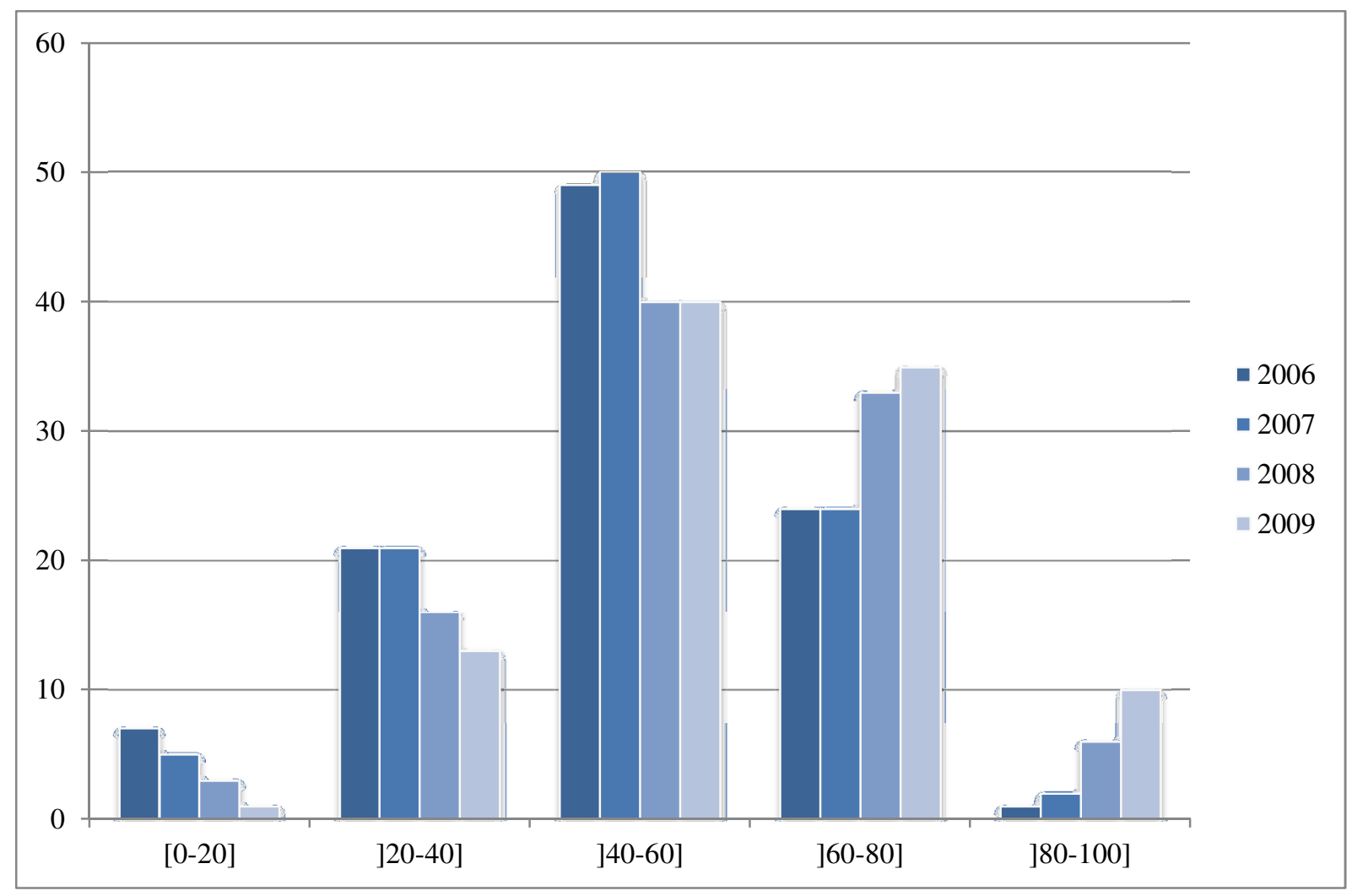


Table 1 - Auditors Strategies and Firm Disclosures

\begin{tabular}{|c|c|c|c|}
\hline & & \multicolumn{2}{|c|}{ Auditor \#1 } \\
\hline & & Corrective actions & No-action \\
\hline \multirow{2}{*}{ Auditor \#2 } & Corrective actions & High disclosures* & High disclosures* \\
\hline & No-action & High disclosures* & Low disclosures \\
\hline \multicolumn{4}{|c|}{$\begin{array}{l}\text { Table } 1 \text { describes the level of disclosures conditionally to auditors' strategies. The socially } \\
\text { optimal outcomes are indicated with a star. }\end{array}$} \\
\hline \multicolumn{4}{|c|}{ Table 2 - Joint-Audit Game with Two Auditors of the Same type } \\
\hline & & \multicolumn{2}{|c|}{ Auditor \#1 } \\
\hline & & Corrective actions & No-action \\
\hline \multirow{2}{*}{ Auditor \#2 } & Corrective actions & $\left(-1 / 2 * \mathrm{C}_{C A} ;-1 / 2 * \mathrm{C}_{C A}\right)$ & $\left(0 ;-\mathrm{C}_{C A}\right)$ \\
\hline & No-action & $\left(-\mathrm{C}_{C A} ; 0\right)$ & $\left(-1 / 2 * \mathrm{C}_{R E P} ;-1 / 2 * \mathrm{C}_{R E P}\right)$ \\
\hline
\end{tabular}

Table 2 describes the game's payoff conditional to the players strategies. $\mathrm{C}_{C A}$ represents the costs of adopting the "corrective actions" strategy, $\mathrm{C}_{R E P}$ are the reputation costs in case of low disclosure.

Table 3 - Joint-Audit Game with a Big-4 and a non-Big-4 Auditor

\begin{tabular}{cccc}
\cline { 3 - 3 } & & \multicolumn{2}{c}{ Big 4 auditor } \\
\cline { 3 - 4 } & & Corrective actions & No-action \\
\hline $\begin{array}{c}\text { non-Big } 4 \\
\text { auditor }\end{array}$ & No-action & $\left(-1 / 2 * \mathrm{C}_{C A} ;-\mathrm{k} / 2 * \mathrm{C}_{C A}\right)$ & $\left(0 ;-\mathrm{k}^{*} \mathrm{C}_{C A}\right)$ \\
\hline
\end{tabular}

Table 3 describes the game's payoff conditional to the players strategies. $\mathrm{C}_{C A}$ represents the costs of adopting the "corrective actions" strategy, $\mathrm{C}_{R E P}$ are the reputation costs in case of low disclosure. 
Table 4 - Summary of the Major Items composing the Impairment Testing Disclosure Index

\begin{tabular}{|c|c|c|}
\hline Main categories & Sub-categories & \# Items \\
\hline $\begin{array}{l}\text { I. Presentation and reference to } \\
\text { Standard IAS } 36 \text { "Impairment of } \\
\text { assets" }\end{array}$ & $\begin{array}{l}\text { 1. Explicit presentation of the alternative Fair Value } \\
\text { and/or Utility Value } \\
\text { 2. Standard IAS } 36 \text { explicitly mentioned }\end{array}$ & 3 \\
\hline $\begin{array}{l}\text { II. Valuation method: fair value or } \\
\text { value-in-use }\end{array}$ & $\begin{array}{l}\text { 3. Methodology explained: DCF (Value in use), Fair } \\
\text { Value or other method }\end{array}$ & 4 \\
\hline III. Methods used & $\begin{array}{l}\text { 4. One approach by cash-generating units or several } \\
\text { approaches }\end{array}$ & 3 \\
\hline IV. Number of cash-generating units & 5. Number of business units $>1$ mentioned & 1 \\
\hline $\begin{array}{l}\text { V. Computation of the cost of } \\
\text { capital }\end{array}$ & $\begin{array}{l}\text { 6. Explicit reference to a model } \\
\text { 7. Tax issues mentioned } \\
\text { 8. Details provided on the computation of the cost of } \\
\text { capital } \\
\text { 9. Formula of computing mentioned }\end{array}$ & 5 \\
\hline VI. Number of discount rates & $\begin{array}{l}\text { 10. Several discount rates used (by cash generating } \\
\text { units) } \\
\text { 11. Details on adjustment methods }\end{array}$ & 8 \\
\hline $\begin{array}{l}\text { VII. Financing neutrality and } \\
\text { discount rate }\end{array}$ & $\begin{array}{l}\text { 12. Neutrality of the financing structure on the discount } \\
\text { rate mentioned }\end{array}$ & 1 \\
\hline VIII. Origin of the discount rate & $\begin{array}{l}\text { 13. Use of independent experts for tests } \\
\text { 14. Use of independent experts and/of financial analysts }\end{array}$ & 3 \\
\hline IX. Cost of capital components & $\begin{array}{l}\text { 15. Discount rate mentioned } \\
\text { 16. Risk-free rate mentioned } \\
\text { 17. "Beta" mentioned } \\
\text { 18. "Beta" of the company or of peer-group firms } \\
\text { mentioned } \\
\text { 19. Equity risk premium mentioned } \\
\text { 20. Target financial structure mentioned }\end{array}$ & 8 \\
\hline $\mathrm{X}$. Impairment test sensitivity & $\begin{array}{l}\text { 21. Sensitivity tests performed } \\
\text { 22. Sensitivity on the cash flows mentioned }\end{array}$ & 2 \\
\hline $\begin{array}{l}\text { XI. Explanation of the variations of } \\
\text { the discount rate }\end{array}$ & 23. Explanations of rates' variations per components & 4 \\
\hline XII. Cash flows & 24. Value in use per se or market data & 4 \\
\hline $\begin{array}{l}\text { XIII. Discount rate \& cash flows } \\
\text { adequacy }\end{array}$ & 25. Adequacy between cash flows and rate mentioned & 1 \\
\hline $\begin{array}{l}\text { XIV. Explicit cash flow projecting } \\
\text { period }\end{array}$ & $\begin{array}{l}\text { 26. Explicit period between forecasts and terminal value } \\
\text { 27. Explicit forecasting period explained } \\
\text { 28. Extrapolation period explained }\end{array}$ & 5 \\
\hline XV. Terminal value & $\begin{array}{l}\text { 29. Methods of terminal value computing mentioned } \\
\text { 30. If several methods mentioned, multiple or infinite } \\
\text { growth rate used }\end{array}$ & 3 \\
\hline
\end{tabular}


Table 5 - Descriptive Statistics of the Sample

Panel A - Univariate Statistics

\begin{tabular}{lccccccccc}
\hline & Unit & $\mathbf{N}$ & Mean & St.Dev & Min & $\mathbf{1}^{\text {st }} \mathbf{Q}$ & Med & $\mathbf{3}^{\text {rd }} \mathbf{Q}$ & Max \\
\hline Big4_Big4 & $(\%)$ & 355 & 41.49 & & & & & & \\
Big4_Small & $(\%)$ & 355 & 55.87 & & & & & & \\
Small_Small & $(\%)$ & 355 & 2.64 & & & & & & \\
Change & $(\%)$ & 355 & 6.42 & & & & & & \\
Score & Pts & 355 & 52.8 & 16.6 & 13.3 & 42.5 & 54.2 & 64.2 & 89.2 \\
Risk & Beta & 355 & 0.84 & 0.32 & 0.18 & 0.61 & 0.84 & 1.05 & 1.60 \\
Size & Ln(mv) & 355 & 7.33 & 1.62 & 1.10 & 6.21 & 7.24 & 8.37 & 11.78 \\
Float & $(\%)$ & 355 & 65.46 & 25.38 & 12.70 & 45.50 & 66.50 & 90.00 & 100.00 \\
Imp & $(\%)$ & 355 & 40.79 & & & & & & \\
\hline
\end{tabular}

Big4_Big4 is a dummy variable equaling 1 if both firm's external auditors are among the four largest audit companies. Big4_Small is a dummy variable equaling 1 if one of the two external auditors is among the four largest audit companies and the other is not. Small_Small is a dummy variable equaling 1 if both firm's external auditor are not among the four largest audit companies. Change is a dummy variable equaling 1 if the firm changes external auditor during the fiscal year. Score is our self-constructed index for firms' impairment related disclosure. Risk is the firm's 5-year beta. Size is the natural logarithm of market value of equity. Float is the percentage of the publicly exchanged part of the firm's equity. Imp is a dummy variable equaling 1 when the firm has an impairment of intangible asset. 
Panel B - Correlation Matrix between Variables (P-Value are indicated in parenthesis)

\begin{tabular}{|c|c|c|c|c|c|c|c|c|c|}
\hline & Big4_Big4 & Big4_Small & Small_Small & Change & Score & Risk & Size & Float & $\operatorname{Imp}$ \\
\hline Big4_Big4 & 1.000 & & & & & & & & \\
\hline Big4_Small & $\begin{array}{c}-0.944 \\
(0.000)\end{array}$ & 1.000 & & & & & & & \\
\hline Small_Small & $\begin{array}{l}-0.143 \\
(0.005)\end{array}$ & $\begin{array}{c}-0.191 \\
(0.000)\end{array}$ & 1.000 & & & & & & \\
\hline Change & $\begin{array}{c}0.001 \\
(0.985)\end{array}$ & $\begin{array}{l}-0.070 \\
(0.229)\end{array}$ & $\begin{array}{c}0.211 \\
(0.000)\end{array}$ & 1.000 & & & & & \\
\hline Score & $\begin{array}{c}0.065 \\
(0.188)\end{array}$ & $\begin{array}{l}-0.076 \\
(0.133)\end{array}$ & $\begin{array}{l}-0.032 \\
(0.532)\end{array}$ & $\begin{array}{c}-0.012 \\
(0.840)\end{array}$ & 1.000 & & & & \\
\hline Risk & $\begin{array}{c}0.198 \\
(0.000)\end{array}$ & $\begin{array}{l}-0.219 \\
(0.000)\end{array}$ & $\begin{array}{c}0.005 \\
(0.925)\end{array}$ & $\begin{array}{c}-0.048 \\
(0.415)\end{array}$ & $\begin{array}{c}0.281 \\
(0.000)\end{array}$ & 1.000 & & & \\
\hline Size & $\begin{array}{c}0.316 \\
(0.000)\end{array}$ & $\begin{array}{c}-0.271 \\
(0.000)\end{array}$ & $\begin{array}{c}-0.171 \\
(0.001)\end{array}$ & $\begin{array}{c}0.003 \\
(0.965)\end{array}$ & $\begin{array}{c}0.134 \\
(0.010)\end{array}$ & $\begin{array}{c}0.213 \\
(0.000)\end{array}$ & 1.000 & & \\
\hline Float & $\begin{array}{c}0.022 \\
(0.668)\end{array}$ & $\begin{array}{c}0.006 \\
(0.901)\end{array}$ & $\begin{array}{l}-0.010 \\
(0.847)\end{array}$ & $\begin{array}{c}0.045 \\
(0.445)\end{array}$ & $\begin{array}{c}0.150 \\
(0.003)\end{array}$ & $\begin{array}{c}0.340 \\
(0.000)\end{array}$ & $\begin{array}{c}0.042 \\
(0.422)\end{array}$ & 1.000 & \\
\hline Imp & $\begin{array}{c}0.079 \\
(0.113)\end{array}$ & $\begin{array}{l}-0.148 \\
(0.003)\end{array}$ & $\begin{array}{c}0.105 \\
(0.037)\end{array}$ & $\begin{array}{c}0.042 \\
(0.468)\end{array}$ & $\begin{array}{c}0.148 \\
(0.003)\end{array}$ & $\begin{array}{c}0.199 \\
(0.000)\end{array}$ & $\begin{array}{c}0.084 \\
(0.104)\end{array}$ & $\begin{array}{c}0.075 \\
(0.135)\end{array}$ & 1.000 \\
\hline
\end{tabular}

Big4_Big4 is a dummy variable equaling 1 if both firm's external auditors are among the four largest audit companies. Big4_Small is a dummy variable equaling 1 if one of the two external auditors is among the four largest audit companies and the other is not. Small_Small is a dummy variable equaling 1 if both firm's external auditor are not among the four largest audit companies. Change is a dummy variable equaling 1 if the firm changes external auditor during the fiscal year. Score is our self-constructed index for firms' impairment related disclosure. Risk is the firm's 5-year beta. Size is the natural logarithm of market value of equity. Float is the percentage of the publicly exchanged part of the firm's equity. Imp is a dummy variable equaling 1 when the firm has an impairment of intangible asset. 
Table 6 - Joint Audit Pair and Impairment-Testing Disclosures

\begin{tabular}{|c|c|c|c|c|c|c|c|c|c|}
\hline & Coeff. & t-stat & P.Value & Coeff. & t-stat & P.Value & Coeff. & t-stat & P.Value \\
\hline Big4_Big4 & $-7.184 * *$ & -2.099 & 0.037 & & & & & & \\
\hline Big4_Small & & & & $6.437 * *$ & 2.398 & 0.017 & & & \\
\hline Small_Small & & & & & & & -6.181 & -1.386 & 0.167 \\
\hline $\operatorname{Imp}$ & 0.366 & 0.310 & 0.757 & 0.715 & 0.609 & 0.543 & 0.922 & 0.779 & 0.437 \\
\hline Risk & $8.685 * * *$ & 3.612 & 0.000 & $6.855^{* * *}$ & 2.784 & 0.006 & $6.175^{* *}$ & 2.489 & 0.013 \\
\hline Size & 1.241 & 0.933 & 0.352 & 1.131 & 0.856 & 0.393 & 1.186 & 0.886 & 0.377 \\
\hline Float & $8.961 * *$ & 2.071 & 0.039 & $10.806^{* *}$ & 2.498 & 0.013 & $11.154 * *$ & 2.556 & 0.011 \\
\hline Y2007 & $2.479 * *$ & 2.251 & 0.025 & $2.383^{* *}$ & 2.174 & 0.031 & $2.233^{* *}$ & 2.025 & 0.044 \\
\hline Y2008 & $7.056 * * *$ & 6.263 & 0.000 & $7.134 * * *$ & 6.359 & 0.000 & $6.931 * * *$ & 6.157 & 0.000 \\
\hline Y2009 & $10.857 * * *$ & 9.491 & 0.000 & $10.794 * * *$ & 9.444 & 0.000 & $10.385^{* * *}$ & 9.167 & 0.000 \\
\hline cons & 27.786 *** & 2.715 & 0.007 & $22.537 * * *$ & 2.245 & 0.026 & $26.375^{* * *}$ & 2.584 & 0.010 \\
\hline $\mathbf{R}^{2}$ & & 0.371 & & & 0.369 & & & 0.359 & \\
\hline Adj. $R^{2}$ & & 0.121 & & & 0.117 & & & 0.104 & \\
\hline $\mathbf{F}$ & & 19.126 & & & 18.476 & & & 17.734 & \\
\hline $\mathbf{P}(\mathbf{F})$ & & 0.000 & & & 0.000 & & & 0.000 & \\
\hline $\mathbf{N}$ & & 355 & & & 355 & & & 355 & \\
\hline $\begin{array}{l}\text { Firm-fixed } \\
\text { effects }\end{array}$ & & (yes) & & & (yes) & & & (yes) & \\
\hline
\end{tabular}

${ }^{*} \mathrm{p}<.1$ (two-sided tests); ${ }^{* *} \mathrm{p}<.05$ (two-sided tests); ${ }^{* * *} \mathrm{p}<.01$ (two-sided tests) 